\title{
A New Way of Life
}

Today was the day, I had waited all week for this moment but now that it's here my nerves are in overdrive. Just last week Dad travelled to Masterton without me and Mum, to make contact with his biological mother. It must have gone well because now we're all headed off to meet the rest of Dad's family.

I didn't have to go to school this morning, which was a bonus. Dad said we would need the whole morning to travel. It's not very often that I get to leave Auckland as this actually would mark the first trip with my parents. Their busy work schedules usually keep us grounded, but this was a special occasion.

My dad was adopted into a European family when he was eight years old. He told me it wasn't his mother's choice to adopt him out, he was taken by a policeman while walking home from school one day. Confused, my dad asked when he would be able to go home. He said the policeman replied with a laugh, "When we find you some better parents." I guess that's when he met Gran and Grandpa. So, most of his life, my dad was in a European family. He said Gran and Grandpa had always been good to him. They even moved to Auckland to give him better opportunities. Here, he went to Kelston Boys' High School and on to AUT where he met my Mum. You know, if I think about it, Dad would have only been a few years younger than me now when he got taken away from his parents. That would have been such a huge adjustment for him. 
Dad drove towards Hamilton, and I was fascinated by the landscape. Auckland was such a concrete jungle, and it had been too long since I had seen the countryside. I wound down my window to take in a breath of fresh air, "ahhhhh" I let out a relieving sigh.

"You alright, Bub?" said Dad from the driver seat.

"Yeah, Dad" I replied, "Just happy to be together, and out of that city!" He smiled at me in the rear-vision mirror.

"Let's grab something to eat before we head out aye?"

Dad pulled up to a truckstop just South of Auckland. He quickly ran in and brought out a bag of goodies.

"Here, Bub," he said handing me a bottle of L\&P and some fish and chips. "The L\&P will help if you feel car sick," I nodded and dug into my lunch. My nerves were still running races in my gut, so I didn't eat much.

We passed a sign saying $40 \mathrm{~km}$ till Masterton. I could tell Dad was nervous. This was his fifth cigarette since we stopped in Palmerston North about 45 minutes ago. The smell of secondhand smoke and the windy country roads made it hard to keep my South of Auckland fish and chips down. I remembered Dad said it would help with car sickness, so I finished the L\&P off.

To get my mind off the butterflies toiling away in my gut, I started to think about getting to the marae. I'd never been to one before. Dad told me earlier that he was Māori, and they had organized a family gathering for his return. A good chance to meet everyone, I guess. This made me nervous. I'm Māori. But I had never been around other Māori people before apart from Dad. The thought scared me. What if they don't like me? I'm pretty much the most uncultured Māori you've ever seen. Mousy brown hair and green eyes. I'm definitely going to stand out! That's if my complete and utter lack of knowledge about the Māori culture doesn't already raise red flags. I feel sick. 
The thoughts racing around my head made me feel even worse. I could feel sickness rising in the back of my throat. My chest was heavy. I needed to get out of the car. It was too small. I was sweating. Droplets were above my upper lip. I started to heave. "Mum. I don't feel well," I managed to say. Quickly, Dad pulled the car to the side of the road and as soon as he stopped, I made a run for the bushes.

Mum and Dad followed. While Mum was stretching and getting some water, Dad came over to comfort me.

"You okay Bene?" he asked with a concern.

"Yeah, Dad, just a bit windy out here, aye?" I replied, wiping my mouth, the taste of regurgitated $L \& P$ and $F \&$ Cs.

"That's the country for yah, kiddo," he smiled at me. "You sure nothing else is bothering you? You've been super quiet the whole way."

I looked at the ground, stones and tar, then back at him. "I'm just a little nervous, it's all going to be so different, what if they don't like me? What if I don't fit in?" I said worryingly. "Hey, no need to worry about that Bene, they will love you. Just be yourself, Bub," he said pulling me into a hug. "To be honest, I'm a little nervous too, this is all so new for me as well."

I looked up at his face, his dark brown hair was neatly gelled back. "Don't worry Dad, me and Mum are here. But you should give up smoking. It's smelly," I instructed cheekily, breaking our hug and running back to the car.

I knew we were close when the road went from smooth to gravel. A very long dirt road. At the end of this road was a building with a red roof, surrounded by trees, everything else around was farmland. I noticed a wooden sign at the entrance "Te Ore Ore Marae." We were finally here. 
As we got out of the car I reached for the sky, stretching all my dormant muscles. As Dad was grabbing a few things from the boot of the car, an old woman greeted him, "Kia Ora whānau" she said cheerfully, pulling Dad in for a long hug. I looked over at this woman. Something seemed very familiar about her, the smile, the soft eyes. "They're like my dad's!" I thought, "Is this his mother? Is this my Nana?"

Before I could ask, I heard my name, "This is Bene, my daughter," Dad introduced. The woman turned to me, gave me a very warm smile, then pulled me into an embrace.

"Kia Ora, Moko" she said, while kissing my cheek.

"Bene," I corrected her.

"Bub, moko means grandchild" Dad laughed, "she knows your name".

"Great!" I thought. "Screwed up already."

Just as my nan introduced herself to my mum, a man came from the building behind the marae, "Whāea, we are ready for the powhiri," he said.

"What's a poor-fiddy?" I asked.

Nan explained as she guided us towards the main entrance, "it's when visitors from a far, or as we say in te reo 'manuhiri' are invited onto the marae in a welcoming ceremony." Nan disappeared. Where'd she go?

As I stepped up to the gates, I had to take a few moments to internalize what I was seeing. There were people for as far as I could see. "Dad must have a huge family" I thought.

There were amazing carvings on the front of the marae; eyes made of paua that reflected beautifully in the sunlight. All of a sudden, everyone was standing, and the air was still. I looked up at Dad for some type of signal. I didn't know what was happening. What's happening? "There's Nanny!" I thought. She's under those red carvings on the big house. I waved big waves, hoping she'd see me. 
That's when Nanny started calling. Straight away, my attention was on her. The sound she made, felt so familiar. Although I knew I hadn't heard anything like it before. The hairs on my neck stood up.

A woman at the front of our group, another nan I think, called back. I feel my dad's hand on my back as he starts to move forward. Mum's walking with us, too. I follow. There is a lot more people here than I thought, and they're all looking at us. "Are they looking at me? I'm white and they're all brown. Am I sticking out?" My stomach burbles, "oh no, my butterflies are back."

After the powwhiri, everyone gathered in the wharekai, I walked through the doors and the aroma of food crammed my nostrils. My tummy grumbled, after that trip and my chuck in the bush I could eat everything.

"Go on, Bene," I heard mum say. "Dig in, Bub." I grabbed a plate and jumped in line ready to fill up there was so much food, boil up, hāngī, steamed pudding and fried bread. I reached for a plate, but Dad stopped me. "Hold off, Bene. Karakia first. Got to bless the kai."

What? This world was so different. Dad never blessed our food before. He doesn't know how to speak Māori, how was he going to do a karakia?

All of a sudden, Dad stood at the end of the table and spoke, "E Ihowa, whakapaingia ènei kai..."

What? Dad speaks Māori? What's going on?

I was a bit hesitant, but I built up the courage to put the foreign food in my mouth. The boil-up was my favourite. A lot of people came over to introduce themselves; Dad's cousins, second cousins, and my nan's brothers and sisters. I have no idea how I'm meant to remember all of their names. There has got to be close to a hundred people here. For Dad. 
After the kai, Nan sent all us kids outside while my parents and the other old people caught up. I didn't want to go by myself, but Nanny promised I will be fine.

There were twelve kids around my age. I sat on the stool outside the wharekai. I watched as they headed towards the front of the marae. I inched closer. The eldest boy cousin, I think his name was Niko, pulled out a guitar and started playing. The girl swung their poi and sung along to his beautiful strumming. They were so talented! Each kid played a role in the song. It would be rude of me to interrupt. I better not interrupt. I don't know how to do that poi stuff, so I just sat back and watched.

Here came my nerves again. I just couldn't find the courage to go talk to them. Why would they want to hang out with me anyway? I'm so boring. Not like them.

For the next half an hour I sat under the shade kicking rocks around with my feet, occasionally looking up when I heard the others laughing. They're probably laughing at me.

"Hey," a familiar voice called, "what you doing over there lone ranger?" My head jolted around.

"Dad," I said, gee, was glad to see him.

"What are you doing over here, Bene? You should be over there, getting to know your whānau."

"Nah," I replied. "I don't know what to say. I don't wanna make a fool of myself." I kicked the rocks again.

Dad put his hand on my chin and brought my eyes to meet his, "Bene," he started, "You're not here because you know everything already, you're here to embrace YOUR culture. It's yours. It's a new way of life for you," he explained. "You never know, there's no such thing as a stupid question, they will teach you a thing or two."

“But Dad, what if they don't like me?” I replied. 
His eyes softened, "Bub, you're new to them as well. They don't get many city folks around these ways. Maybe you could teach them something about city life? I'm sure they will love you." I felt better.

Feeling more confident, I decided to make the first move. I gave Dad, a hug and headed over to where the other kids were still singing and swinging poi.

"Bene," Dad called, "one last thing." He reached into his back pocket, a pulled out a necklace with beautiful green stone in the centre. "Something to make you feel more at home." Excited, I turned around and let dad put the pounamu on my neck.

"It's beautiful" I said, as I held it in my hand.

All of a sudden, the butterflies in my stomach were gone. "Thanks Dad," I said pulling him into a hug.

"Oh, one last thing Dad," I kissed him on the cheek, and whispered, "I love you. Welcome home."

"Love you too, Bub." 